\title{
Temporary Water Markets in Oman
}

\section{Slim Zekri*, Hemesiri Kotagama and Houcine Boughanmi}

\author{
Department of Agricultural Economics and Rural Studies \\ College of Agricultural and Marine Sciences \\ Sultan Qaboos University \\ P.O. Box 34, Al-Khod 123, Muscat, Sultanate of Oman
}

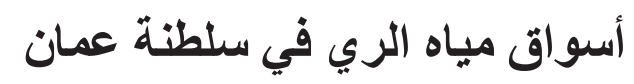

سليم زكري و هدسيري كوتاجاما وحسين البو غانمي

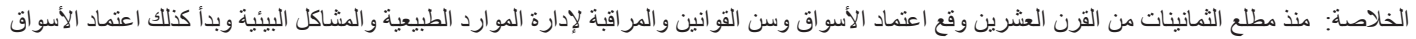

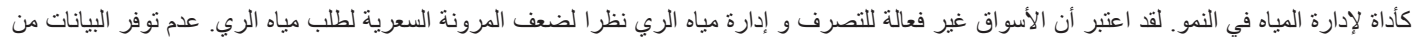

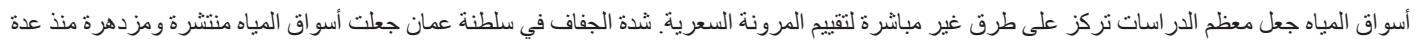

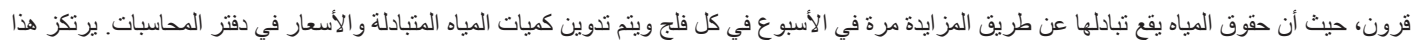

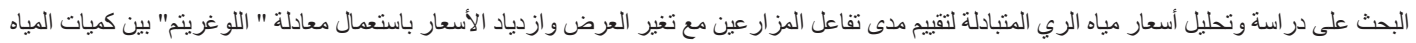

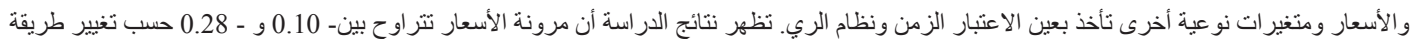

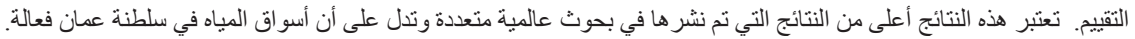

ABSTRACT: Market vis-à-vis command and control approaches have been widely adopted in natural resource and environmental management since the 1980s. Adoption of markets in managing irrigation water resources is also emerging. It has been argued that markets are ineffective in managing the demand for irrigation water due to very low price elasticity. Most studies have been based on mathematical models simulating water markets and not on observed prices and quantities in real water markets since such data are rarely available. In Oman, perhaps in response to the extreme scarcity of water, elaborate water demand management institutions emulating markets have evolved and have been used for centuries. Water entitlements are leased based on prices through a community auction. The traded quantities of water and related prices have been recorded. This study uses this unique data set to estimate the elasticity of irrigation water. A log function on quantity and price of irrigation water is used with dummy variables on time and type of irrigation system. The price elasticity varies from - 0.10 to -0.28 , depending on the specifications of the econometric model. These estimates are higher than most estimates reported in past studies ${ }_{2}$ indicating the efficacy of the indigenous market-based irrigation water management institution adopted in Oman.

Keywords: Water market, price elasticity, price analysis, falaj.

\section{Introduction}

The advantage of market-based approaches in improving efficiency over command and control approaches in resource management has been theoretically established (Randall, 1987). There is substantial literature evaluating the successes and failures of the adoption of market based policy instruments in natural resource management (Sterner,

\footnotetext{
* Corresponding author. E-mail: slim@squ.edu.om
} 
2003). The choice of appropriate policy is dependent prmaily upon understanding potential policy response, which is empirically estimated as elasticity.

Since the early 1990s, market based volumetric pricing has been proposed to manage demand for irrigation water (De Charlotte and Perry, 2002; Schoengold et al., 2005). Water price would be an incentive for efficient use of water, to recover the cost of water supply and enable further investments. A primary requirement for water pricing, to induce water saving behavior, is that the price of irrigation water be sufficiently elastic to generate a response from water users. Appels et al. (2004) provide a comprehensive review of other requirements for use of markets for irrigation demand management. There are several factors that may render the use of markets ineffective in water management such as high implementation costs, externalities, generation of inequities and social non-acceptance. It has been argued that water pricing is an ineffective means of managing water because elasticity $(\alpha)$ is low, due to the low substitutability of water in agriculture. It has also been found that $\alpha$ is $\mathrm{low}_{2}$ particularly at reduced water prices and where the cost for water is negligible (Molle and Turral, 2004). The $\alpha$ also depends on a host of other factors such as the mix of crops. The $\alpha$ is low in perennial cropping systems and tends to vary over space and time (Appels et al., 2004).

Despite the policy significance and conceptual simplicity, there are few empirical studies that have estimated $\alpha$ (Appels et al., 2004: Schoengold et al., 2005). The major reason for the lack of such studies is due to the paucity of data on observed market prices and quantities of water traded (Appels, 2004; Brookshire et al., 2004). Therefore, most studies have used simulated data in estimating a (Appels, 2004; Schoengold et al., 2005) and are not based on observed farmers' behavior.

Appels et al. (2004) comprehensively reviewed studies undertaken between 1986 and 2004 on responsiveness of demand for irrigation water. All studies based on simulated prices obtained through mathematical models and water shadow prices rather than observed data on quantity and price of irrigation water. The estimated $\alpha$, based on reviewed studies ranges from 0.00 to -3.80 , with an extreme estimate of -14.10 . The $\alpha$ is higher in the long run than the short run. Further the $\alpha$ is low at low water prices and increases with increasing water prices. The $\alpha$ also varies depending on the type of function/model used in the estimation. Schoengold et al. (2005), based on a panel study of water demand, have estimated the $\alpha$ as -0.40 . It is claimed that this estimate is higher than most previous estimates, indicating the potential to use water pricing to manage irrigation water demand. This estimate of $\alpha$ is the same as residential water use elasticity. In a meta-analysis of residential water use elasticity was found to be -0.41 (Dalhuisen et al., 2003).

This study estimates the irrigation water demand elasticity based on market prices and quantities as observed in small community-managed irrigation systems in Oman. The following section provides a brief description of the irrigation water management institutions in Oman. The subsequent section presents the analytical methodology, followed by results. Finally the implications of the results on the potential use of markets in managing water demand are discussed.

\section{Water Management Institutions in Oman}

Oman relies on groundwater and desalinated water. Desalinated water is used exclusively for urban and industrial purposes. Of the ground water, $93 \%$ is used in the agricultural sector. Water pumping through wells represents $67 \%$ while the traditional irrigation (aflaj, singula falaj) share is $33 \%$ of total groundwater use. This study is based on data collected from aflaj systems.

Aflaj irrigation systems are a long-established indigenous engineering method and a social heritage of Oman. Aflaj is a network of man-made underground galleries conveying groundwater to a community for domestic and irrigation uses. There are three aflaj types in Oman. Daudi aflaj are usually located in plains, derive water from alluvial aquifers and are characterized by relatively stable water flow rate throughout the year. Ghaili aflaj involve a diversion of a quasi-perennial flow in the surface gravels of a wadi (river) into a channel (Wilkinson, 1977); since these aflaj depend on water collected in pools that form in depression areas of wadis, they tend to dry up during drought years. Finally, Aini aflaj consist of one or more natural springs diverted through a channel (MRMEW, 2002). This study is based on data collected from Daudi and Ghaili afalaj.

The community has managed the aflaj for centuries. A general belief is that large numbers of 
Table 1. Summary of features of the aflaj studied.

\begin{tabular}{lccccc}
\hline Name of falaj & Type & $\begin{array}{c}\text { Irrigated area } \\
\text { Ha }\end{array}$ & $\begin{array}{c}\text { Average flow } \\
\text { L/Sec }\end{array}$ & $\begin{array}{c}\text { Flow/irrigated } \\
\text { area } \\
\text { L/Sec/Ha }\end{array}$ & $\begin{array}{c}\text { Period for } \\
\text { which data is } \\
\text { available }\end{array}$ \\
\hline Al-Farfara & Daudi & 40.2 & 13 & 0.33 & $2001-2003$ \\
Mehaidath & Daudi & 28.4 & 106 & 3.72 & $1997-2003$ \\
Al-Balfai & Ghaili & 17.1 & 32 & 1.87 & $1997-2003$ \\
Al-Samdi & Ghaili & 80.0 & 74 & 0.94 & $1994-2003$ \\
\hline
\end{tabular}

small farmers may find it difficult to cooperate and manage irrigation systems successfully. The large number of small irrigated farms translates into high transaction costs precluding collective action. Besides the transaction costs, difficulties arise in arriving at consensus-based decisions on water sharing too, due to the large number of farmers (Shah et al., 2002). This problem of collective action is overcome in irrigation water management in Oman by the falaj institution. Two types of water rights prevail in the falaj; these are private rights and common rights. The private water rights are explicit rights with property licenses owned by individuals and recognized by courts. The common water rights are created by pooling together a set of private water rights based on a percentage of individual shares. These rights are mainly established to generate income for falaj maintenance and operating expenditures. The common water rights are auctioned weekly, semi-annually, or on an annual basis (Zekri and Al-Marshudi, 2006). The income raised from the sale of common water rights finances the operating and management costs of the systems. The manager of the falaj is a person legally authorized to manage the affairs of the falaj's commonly owned water rights. He is elected among the community of water rights' owners. Aflaj managers' main roles are auctioning common water rights and deciding on expenditures on operation and maintenance of the falaj. He reports to falaj shareholders on returns and expenses on a yearly basis. In cases where water auction income does not cover operating and maintenance costs, shareholders pay the difference proportionately to the water rights owned. The manager receives 5 to $7 \%$ of water auction income for his services.

Farmers are price-takers and cannot strategically affect water market prices given the large number of farmers. A bidding process for common water rights generates a weekly water price. Each water right is leased to the farmer offering the highest price. Different water shares are auctioned, with a minimum timing for any share from half an hour up to six hours. The total shares offered for bidding add up to 24 hours. Any farmer from the community can participate in the auction. Prices are regularly registered in the falaj book. Each water share is registered with its corresponding price and time-share. The Ministry of Regional Municipalities, Environment and Water Resources (MRMEWR) monitored a sample of Aflaj for water flow and quality. The availability of flow measures allow the transformation of time shares into volumetric measures (in cubic meters) which are used in this study.

\section{Methods}

The prices and quantities of water auctioned weekly in four aflaj representing two falaj types over the years 1994 to 2003 were used in this study (Table 1). The water quantities and prices are based on records maintained by aflaj managers and MRMEWR.

The four aflaj considered in this study are situated in the region of Samail, in Oman, within a radius of about $15 \mathrm{Km}$. The same climate and soil type prevail in the area. Average rainfall is $81 \mathrm{~mm} /$ year, occurring in the form of sparse and irregular winter storms that result in large run-off flows through wadi (rivers). Most of the water infiltrates to the aquifers linked to the aflaj (Al-Qurashi, 2002). Winter is mild with temperatures ranging from 15 to $28^{\circ} \mathrm{C}$. Summer, lasting from April until mid of October, is hot with temperatures varying between 33 and $46{ }^{\circ} \mathrm{C}$ and humidity reaching up to $90 \%$ during summer. Date palms are the major crop cultivated in the aflaj command areas. Vegetables are intercropped under the palm trees during the winter season. The main vegetables cropped are tomato, cucumber, and lettuce. Alfalfa and rhodes grass are also cultivated. 
Table 2. Statistics of quantities of water traded and prices by falaj and falaj types.

\begin{tabular}{|c|c|c|c|c|}
\hline \multirow[t]{2}{*}{ Falaj } & \multicolumn{2}{|c|}{$\begin{array}{c}\text { Quantity of water auctioned and } \\
\text { supplied weekly }\left(\mathrm{m}^{3}\right)\end{array}$} & \multicolumn{2}{|c|}{ Price of water Baisa $/ \mathbf{m}^{3}\left(\mathbf{S U S} / \mathrm{m}^{3}\right)$} \\
\hline & Mean & Standard Deviation & Mean & Standard Deviation \\
\hline $\begin{array}{l}\text { Al-Farfara } \\
(\mathrm{n}=163)\end{array}$ & 1138 & 363 & $\begin{array}{r}22.95 \\
(0.060)\end{array}$ & 7.76 \\
\hline $\begin{array}{l}\text { Mehaidath } \\
(\mathrm{n}=324)\end{array}$ & 9753 & 3171 & $\begin{array}{r}5.27 \\
(0.014)\end{array}$ & 11.11 \\
\hline $\begin{array}{l}\text { Al-Balfai } \\
(\mathrm{n}=294)\end{array}$ & 2694 & 1640 & $\begin{array}{r}25.02 \\
(0.065)\end{array}$ & 33.81 \\
\hline $\begin{array}{l}\text { Al Samdi } \\
(\mathrm{n}=397)\end{array}$ & 5018 & 1754 & $\begin{array}{r}19.97 \\
(0.052)\end{array}$ & 33.19 \\
\hline $\begin{array}{l}\text { Daudi falaj type } \\
(\mathrm{n}=487)\end{array}$ & 6870 & 4826 & $\begin{array}{r}11.19 \\
(0.029)\end{array}$ & 13.11 \\
\hline $\begin{array}{l}\text { Ghaili falaj type } \\
(\mathrm{n}=691)\end{array}$ & 4041 & 2069 & $\begin{array}{r}22.12 \\
(0.058)\end{array}$ & 33.53 \\
\hline $\begin{array}{l}\text { Pooled } \\
(\mathrm{n}=1179)\end{array}$ & 5208 & 375 & $\begin{array}{r}17.59 \\
(0.046)\end{array}$ & 27.54 \\
\hline
\end{tabular}

Note: 1 Omani Riyal $=1000$ Omani Baisa $=2.6$ US\$.

Water demand functions have been generally estimated using linear, log-log or log-linear functional forms (Hanemann, 1998; quoted by Schoengold, 2005). The best fit for the data in this study was given by a log-log function. Hence, elasticity was estimated using a log-log function of quantity and price as given below. Estimations were made by adding control variables of the falaj (4 aflaj) and year (1994 to 2003) to represent space and time variations. where,

$$
\operatorname{Ln} \mathrm{Q}_{\mathrm{if}}=\alpha_{0}+\alpha_{1} \operatorname{Ln} \mathrm{P}_{\mathrm{if}}+\alpha_{2} \mathrm{D}_{\mathrm{f}}+\alpha_{3} \mathrm{D}_{\mathrm{y}}+\mathrm{e}_{\mathrm{if}}
$$

$Q_{\text {if }}=$ Quantity of water auctioned (cubic meter X 100) at the $i^{\text {th }}$ auction and $\mathrm{f}^{\text {h }}$ falaj.

$P_{\text {if }}=$ Price of water at the $i^{\text {th }}$ auction and $\mathrm{f}^{\text {h }}$ falaj.

$\mathrm{D}_{\mathrm{f}}=$ Dummy on 4 aflaj.

$D_{y}=$ Dummy on years.

$\mathrm{e}_{\mathrm{if}}=$ Error term of the $\mathrm{i}^{\text {th }}$ auction and $\mathrm{f}^{\text {th }}$ falaj.

$\alpha=$ Intercept $\left(\alpha_{0}\right)$ and coefficients $\left(\alpha_{1} \ldots \alpha_{4}\right)$

\section{Results}

Figures 1(a) and 1(b) show the trends in quantity of water traded and the prices over years. The negative relationship between quantity of water traded and price is clearly observed. The quantity of water traded has decreased by $42 \%$ and water prices have increased by nearly $132 \%$ over the years of study.

Table 2 shows the average quantity of water traded weekly and the average price of the 4 aflaj and 2 aflaj types. The quantities supplied differ among falaj according to the falaj's natural flow. The higher the flow the higher the quantity auctioned and supplied. The water trade consists of renting a 24 hours water time share owned by the falaj community on a weekly basis. Thus the common water share leased represents 1 out of 7 days or $14.3 \%$ of total falaj water. The supply, in terms of time share, is thus fixed and does not vary from one week to another, except for variation due to the falaj's flow.

The prices of water are shown in column 4 of Table 2 and are expressed in Baisa $/ \mathrm{m}^{3}$ as well as in $\$ \mathrm{US} / \mathrm{m}^{3}$. On average, prices vary from a low of 5.27 Baisa $/ \mathrm{m}^{3}$ for Mehaidath to $25.02 \mathrm{Baisa} / \mathrm{m}^{3}$ for Al-Balfai. The average price for the four falaj is 17.59 Baisas $/ \mathrm{m}^{3}$ or US $\$ 0.046 / \mathrm{m}^{3}$. Since the same climate, soil and socio-economic conditions prevail it 


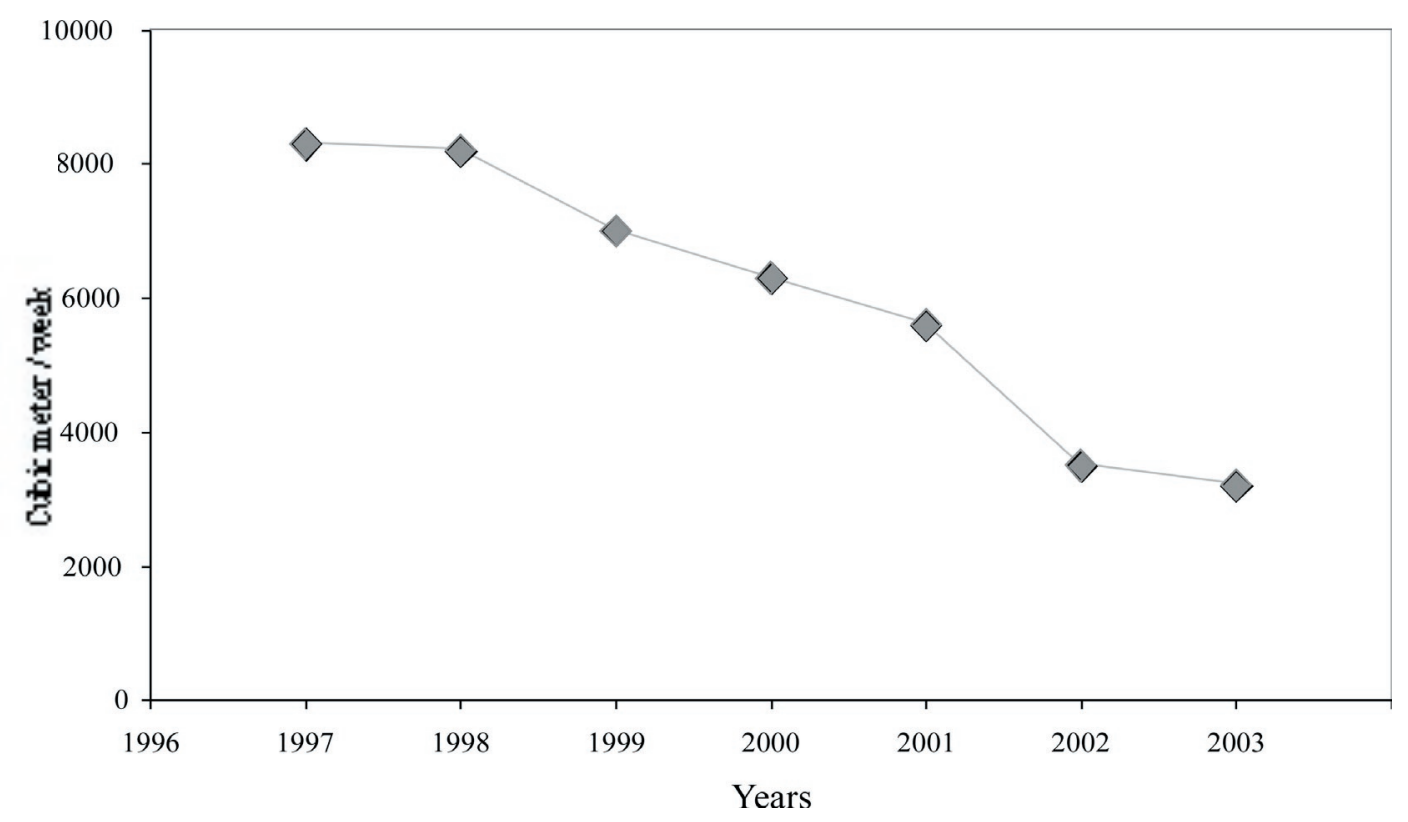

Figure 1 (a). Trend of quantity of water traded over time.

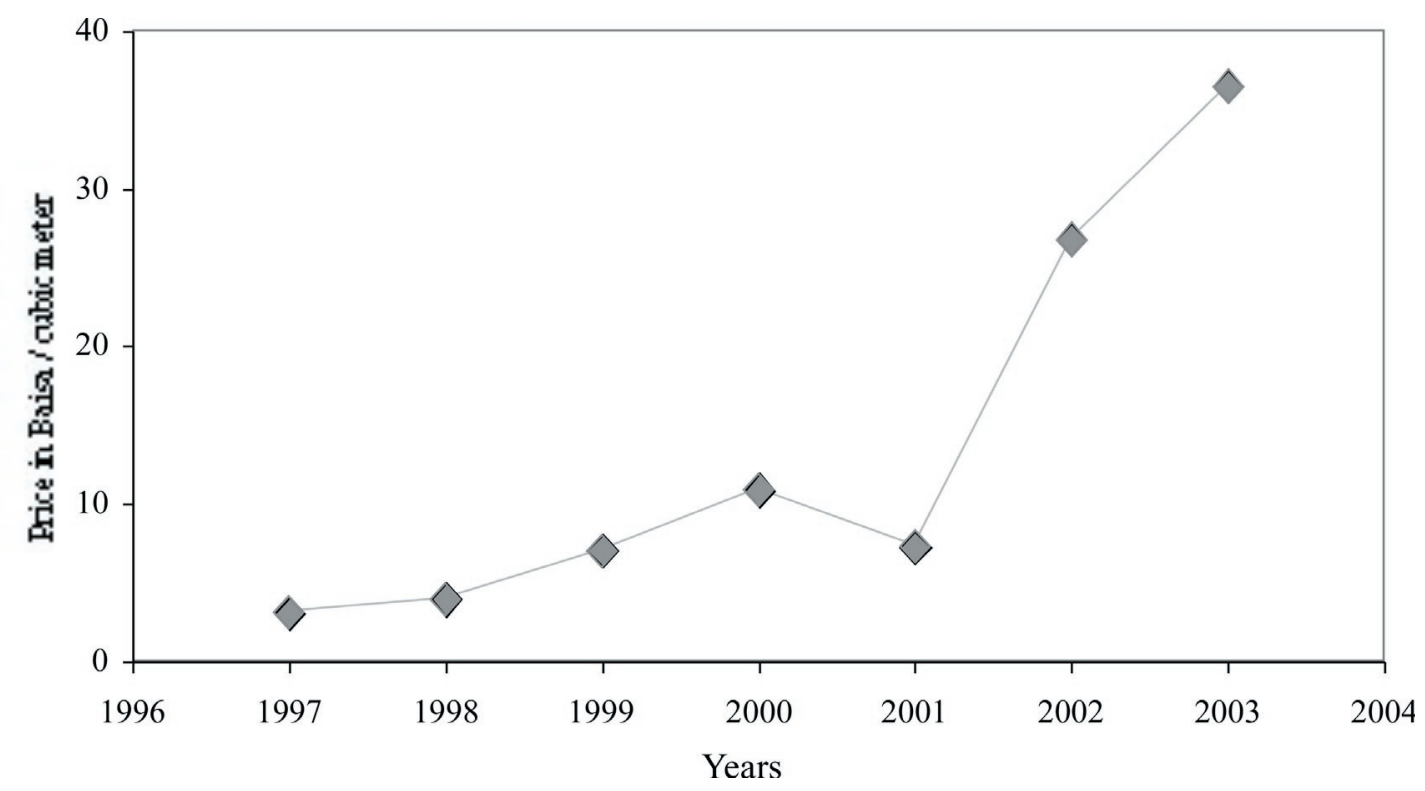

Figure 1 (b). Trend of mean price over time. 
Table 3. Estimates of water demand functions based on pooled data (4 falaj and over time 1994-2003).

\begin{tabular}{|c|c|c|c|}
\hline Independent Variable & Model 1 & Model 2 & Model 3 \\
\hline 1. Intercept & $\begin{array}{r}5.19 \\
(89.65)\end{array}$ & $\begin{array}{r}5.11 \\
(47.28)\end{array}$ & $\begin{array}{r}4.17 \\
(47.81)\end{array}$ \\
\hline 2. $\operatorname{Ln} P_{t j}$ & $\begin{array}{r}-0.20 \\
(-24.64)\end{array}$ & $\begin{array}{r}-0.28 \\
(-22.45)\end{array}$ & $\begin{array}{r}-0.10 \\
(-10.48)\end{array}$ \\
\hline \multicolumn{4}{|c|}{ 3. Falaj dummy (Base is Al-Samdi) } \\
\hline i. Al-Farfara & $\begin{array}{l}-126.00 \\
(-34.94)\end{array}$ & & $\begin{array}{r}-1.11 \\
(-30.42)\end{array}$ \\
\hline ii. Mehaidath & $\begin{array}{r}0.28 \\
(8.66)\end{array}$ & & $\begin{array}{r}0.41 \\
(12.16)\end{array}$ \\
\hline iii. Al-Balfai & $\begin{array}{r}-0.68 \\
(-23.04)\end{array}$ & & $\begin{array}{r}-0.74 \\
(-25.58)\end{array}$ \\
\hline \multicolumn{4}{|c|}{ 4. Year dummy (Base is year 2003) } \\
\hline i. 1994 & & $\begin{array}{r}0.55 \\
(5.07)\end{array}$ & $\begin{array}{r}0.34 \\
(4.93)\end{array}$ \\
\hline ii. 1995 & & $\begin{array}{r}0.43 \\
(4.79)\end{array}$ & $\begin{array}{r}0.23 \\
(3.77)\end{array}$ \\
\hline iii. 1996 & & $\begin{array}{r}0.77 \\
(7.14)\end{array}$ & $\begin{array}{r}0.48 \\
(6.99)\end{array}$ \\
\hline iv. 1997 & & $\begin{array}{r}0.56 \\
(6.76)\end{array}$ & $\begin{array}{r}0.71 \\
(13.23)\end{array}$ \\
\hline v. 1998 & & $\begin{array}{r}0.61 \\
(8.29)\end{array}$ & $\begin{array}{r}0.65 \\
(13.71)\end{array}$ \\
\hline vi. 1999 & & $\begin{array}{r}0.54 \\
(7.52)\end{array}$ & $\begin{array}{r}0.56 \\
(12.11)\end{array}$ \\
\hline vii. 2000 & & $\begin{array}{r}0.42 \\
(6.18)\end{array}$ & $\begin{array}{r}0.40 \\
(9.13)\end{array}$ \\
\hline viii. 2001 & & $\begin{array}{r}0.36 \\
(5.67)\end{array}$ & $\begin{array}{r}0.45 \\
(10.92)\end{array}$ \\
\hline ix. 2002 & & $\begin{array}{r}0.19 \\
(3.44)\end{array}$ & $\begin{array}{r}0.20 \\
(5.98)\end{array}$ \\
\hline Adjusted $\mathrm{R}^{2}$ & 0.80 & 0.55 & 0.84 \\
\hline
\end{tabular}

Note: The numbers within parenthesis are the $t$ values. All the coefficients are significant at 95\% level of confidence. The blanks indicate that the variable was not included in the model.

is surprising to find a great difference in water price, particularly between Mehaidath and the other 3 falaj. However, Mehaidath has a substantially higher water flow/ha, which explains the low price. Water prices should not converge, as there is no water transfer between aflaj, due to the absence of infrastructure for such a purpose.

The estimates of the demand models based on 1179 observations of the pooled data (over years and the 4 falaj) are given in Table 3. All the estimated models have reasonably high adjusted $\mathrm{R}^{2}$. Model 3 has the highest $\mathrm{R}^{2}$ of 0.84 with all coefficients significant at $95 \%$ level of confidence. The signs of coefficients, particularly of the price variable, are consistent with expectations. The individual falaj has a significant impact on the quantity of water traded. It is also revealed that a significant difference exists in the quantity of water traded over years. The $\alpha_{1}$ 
ranges between -0.10 (model 3 ) and -0.28 (model 2). These estimates of $\alpha_{1}$ are consistent and fall within the range of estimates reported in previous studies; in congruence with Schoengold et al. (2005), the $\alpha_{1}$ estimates in this study are reasonably high, though less than one. These estimates are high in relation to the expectation of low $\alpha_{1}$ estimates for perennial crops such as date palms.

The present study indicates that water price could be used as a tool to manage irrigation water demand efficiently as farmers' response to price is tangible. The traditional aflaj irrigation water management institution emulates markets effectively. It shows the possibility of using indigenous traditional institutions to meet present day expectations of using market-based approaches in irrigation water demand management. It also needs to be recognized that, even if the elasticity of demand is considered to be low, and given the high quantity of water used for agricultural purposes, the water savings will be substantial. The irrigation water prices in the study area have increased substantially in response to water supply decrease. Such adjustments are made systematically via the market without the need for any government intervention. The water market prices are proving to be an excellent signal to farmers regarding the quantities leased.

The development of institutions, such as defining water rights and introducing trading mechanisms to use the market processes, is generally difficult, since it may be costly and may not be socially accepted (De Charlotte and Perry, 2002). The advantage in Oman is that such institutions are already in place and thus should be preserved and encouraged.

\section{Conclusions}

Since the 1980s there has been an interest in using market-based approaches to manage irrigation water demand. The feasibility of such an approach depends, among other factors, on the elasticity of water demand. It has generally been believed that the elasticity of water demand is very low, particularly at low water prices. Few studies have empirically estimated the elasticity of water demand. These studies have mostly used simulated data to analyze (on an ex-ante basis) farmers' reactions to changes in water prices. Such models were used because of the lack of real observed prices and quantities in operational water markets.
This study uses observed data on prices and quantities of aflaj irrigation systems in Oman to estimate $\alpha_{1}$.

The community, ingeniously emulating the markets, manages the aflaj irrigation systems. The water price elasticity estimated in this study was found to be within the range of previous studies and is reasonably high, despite the low water prices that had prevailed in the past and the cultivation of perennials. It also establishes the potential to use market-based approaches to manage demand for irrigation water. Follow-up studies need to be done on the nature of adaptations at the farm level to increasing water prices over time, such as land use and cropping systems and technological adoption in the long run.

\section{References}

Al-Qurashi, A.M. 2002. Effects of rainfall and wadi flows on aflaj. Paper Presented at the Oman International Conference on the Development and Management of Water Conveyance Systems. Ministry of Regional Municipalities, Environment and Water Resources, 18-20 May 2002, Muscat. Sultanate of Oman. pp 193-207.

Appels, D., D. Robert and D. Gavan. 2004. Responsiveness of demand for irrigation water: A focus on the Southern Murray-Darling Basin. Staff Working Paper, Australian Government, Productivity Commission. 82 pages.

Brookshire, D.S., B. Colby, M. Ewers and P.T. Ganderston. 2004. Market prices for water in the semi-arid west of the United States. Water Resources Research 40:1-8.

Dalhuisen, J.M., R.J.G.M. Florax, H.L.F. De Groot and P. Nijkamp. 2003. Price elasticity of residential water demand: a meta analysis. Land Economics 79:292-308.

De Charlotte, F. and C. Perry. 2002. Why is irrigation water demand inelastic at low price ranges? Paper Presented at the Conference on Irrigation Water Policies: Micro and Macro Considerations, International Water Management Institute, Agadir, Morocco, 15-17 June 2002. pp 1-20.

Molle, F. and H. Turral. 2004. Demand management in a basin perspective: is the potential for water saving overestimated? Paper Presented at the International Water Demand Management Conference, Dead Sea, Jordan, 30 May - 3 June 2004. 
MRMEWR (Ministry of Regional Municipalities, Environment and Water Resources). 2002. Aflaj in the Sultanate of Oman. International Printing Press, Sultanate of Oman.

Randall, A. 1987. Resource Economics: An Economic Approach to Natural Resource and Environmental Policy, Second Edition, John Wiley and Sons.

Schoengold, K., D.L. Sunding and G. Moreno. 2005. Panel estimation of an agricultural water demand function, http://are.berkeley.edu/-sunding/ workingpapers/water. pp 1-23.

Shah, T., B.V. Koppen, D. Merry, M. Lange and M. Samad. 2002. Institutional alternatives in African smallholder irrigation: Lessons from international experience with irrigation management transfer. IWMI, Research Report No. 60.

Sterner, T. 2003. Policy instruments for environmental and natural resource management. Resources for the Future. The World Bank, Swedish International Development Cooperation Agency.

Wilkinson, J.C. 1977. Water and tribal settlement in Southeast Arabia. Oxford Research Studies in Geography,: Clarendon Press. Oxford.

Zekri, S. and A. Al-Marshudi. 2006. A Millenarian water rights system and water markets in Oman. WSTA Seventh Gulf Water Conference, 19-23 November 2005. Water International (under review). 